\title{
Organizational (Non-) Adoption of Legally Obliged Energy-Saving Technologies: Why (Not) Comply?
}

\author{
Carlijn G. C. van Helmond and Robert A. W. Kok*
}

check for updates

Citation: van Helmond, C.G.C.; Kok, R.A.W. Organizational (Non-) Adoption of Legally Obliged Energy-Saving Technologies: Why (Not) Comply? Sustainability 2022, 14, 1511. https://doi.org/ $10.3390 /$ su14031511

Academic Editors: Josep Llach, Andrea Bikfalvi and Rodolfo de Castro

Received: 14 October 2021 Accepted: 24 January 2022 Published: 28 January 2022

Publisher's Note: MDPI stays neutral with regard to jurisdictional claims in published maps and institutional affiliations.

Copyright: () 2022 by the authors Licensee MDPI, Basel, Switzerland. This article is an open access article distributed under the terms and conditions of the Creative Commons Attribution (CC BY) license (https:// creativecommons.org/licenses/by/ $4.0 /)$.
Institute for Management Research, Radboud University, P.O. Box 9108, 6500 HK Nijmegen, The Netherlands; carlijnvanhelmond@gmail.com

* Correspondence: robert.kok@ru.nl; Tel.: +31-24-361-1922

\begin{abstract}
Although there are organizations that have adopted legally imposed measures regarding energy-saving technologies, up until now, there has been a lot of unused energy-saving potential. Based on existing theories, such as the adoption theory and the institutional theory, this exploratory research investigates the reasons for firms to (or not to) adopt energy-saving technologies, even though they are legally obligated, and it has a positive impact on economic organizational performance. A "multiple mini-case" study, with six cases in the Dutch metalworking/electrical engineering sector and in the synthetic material/rubber sector, were conducted. Results show that, nowadays, organizations do not feel any regulatory pressures as they are not aware of the existence of the concerned legal obligations, e.g., where an organization's self-awareness (of the relative advantages of the technologies) begins to play the most important role. To adopt the technologies, decisionmakers must be convinced that adopting energy-saving technologies involves advantages for the organization and that the payback time is sufficient. Financial dilemmas negatively influence these adoption processes. Lastly, the continuous intentions of organizations to adopt energy-saving technologies appear to be positively related to the number of adopted technologies.
\end{abstract}

Keywords: regulatory pressure; innovation; energy-saving technology; organizational adoption; SME

\section{Introduction}

Nowadays, governments worldwide are enacting more policies to stimulate energyefficient technologies within organizations [1]. These energy-saving technologies are expected to have positive impacts on environmental and economic performances [2], although the relationship with economic organizational performance is not always clear [3]. Some technologies are not only used to save energy, they are also used to decrease the energy expenses in organizations. One example of such an energy-saving measure is the use of a compressor with adjustable rotational frequency, for "not-in-use" hours or when using a compressor for power/heat purposes.

Though many organizations have adopted technologies imposed by governmental laws, up until now, there has been a lot of energy-saving potential-unused for service and industrial organizations [4]; moreover, differences in the adoption of energy-saving technologies (between countries and sectors) are large [5]. Researchers have investigated the factors influencing the adoption of energy-saving technologies, including the environmental policies of taxation, subsidies, standards, quotas and the ETS-system [2,5-7], economic and environmental considerations, e.g., [8,9], social and personal considerations, e.g., [10], and firm and technology characteristics, e.g., [11,12]. See Fu, Kok [13] for a broad overview of factors influencing the adoption of sustainable process technologies, including energysaving technologies, based on a systematic literature review. Whereas previous studies have increased our understanding on the effects of institutional pressures (e.g., in adopting energy-saving technologies), the adoption processes influenced by legal obligations that demand energy-saving investment behaviors from firms, have not been investigated. 
Furthermore, the reasons for not adopting energy-saving technologies have hardly been investigated. Organizational adoption studies presume that the adoption process is reduced to the adoption decision, is voluntary, or that researchers do not mention it [14,15]. Most adoption studies focus on the factors that enhance adoption rather than the factors that inhibit it $[14,16]$. However, non-adoption is not the mirror image of the adoption decision; it represents a different form of behavior, where different explaining factors play a role that is almost totally ignored in adoption research [16]. To the best of our knowledge, current research also disregards the non-adoption of sustainable energy-saving technology. Nonadoption is typically relevant when it falls under the jurisdiction of the law that demands energy-saving investment behavior of organizations.

Legal obligations resulting from governmental laws can qualify as coercive pressures described by institutional theory, e.g., [17]. Coercive pressures, represented by governmental regulations, have been widely investigated in the past, and are generally important for proactive environmental strategies [18], and particularly important in the adoption of sustainable process technologies $[19,20]$. One example of this is the environmental control law and its accompanying "general environmental control terms for institutions by the Royal Decree" (Article 2.15) in The Netherlands. This law is designed to force a considerable number of Dutch organizations (mainly small and medium-sized enterprises (SMEs), such as metalworking firms, swimming pools, and transport firms) to take all energy-saving measures that have a maximum payback time of five years [21]. Adopting these energy-saving measures is expected to have a positive impact on economic organizational performances (and because of that, a stronger competitive position) in a five-year period. These measures do not only save energy, they also decrease the energy expenses in organizations. In this case, the research shows that, although there is a law that obliges organizations to adopt energy-saving technologies, this is not accomplished in practice [21]. Dutch service- and industrial organizations can save between 58 and 94 petajoules of energy if they all comply with the law, reducing $\mathrm{CO}_{2}$ between 2.8 and 4.7 megatons, respectively [21]. In the case of the environmental control law in The Netherlands, half of the municipalities that are responsible for keeping the environmental control law, do not, in all tasks, take this part of the law into account during inspection and maintenance, and when granting licenses [21]. It is unclear as to why organizations have not adopted the energy-saving technologies that fall under the jurisdiction of this law.

Therefore, this exploratory research investigates the factors that influence firms to adopt (or not to adopt) energy-saving technologies, even though they are legally obligated to, and it has a positive impact on economic organizational performance. In the next section, we discuss the current literature and theories concerning this subject and the preliminary expectations of this research. Subsequently, we present the research method and an analysis of the results. Finally, we present a conclusion along with further recommendations.

\section{Theoretical Background}

\subsection{Organizational Adoption and Energy-Saving Technologies}

Technology adoption is described from different theoretical perspectives, e.g., [14]. Based on Rogers [15] and Damanpour [22], adoption is defined as the activities from the first awareness of the need to implement a technology to the final routinizing of the technology, and all of the activities in between. This technology is developed by the organization itself or purchased from suppliers. In either case, if the eventual goal of this behavior is to implement the technology, it is considered adoption behavior.

Energy-saving technologies should not be confused with energy efficient technologies. Energy efficiency concerns "the technical ratio between the quantity of primary or final energy consumed and the maximum quantity of energy services obtainable (heating, lighting, cooling, mobility, and others), whilst energy-saving addresses the reduction of final energy consumption, through energy efficiency improvement or behavioral change" [23] (p. 4787). As alternatives to energy-saving technologies, organizations could adopt renewable energy technologies or renewable energy contracts. Renewable energy technologies are based on 
energy sources that are continually replenished by nature and derived directly from the sun, indirectly from the sun, or from other natural movements and mechanisms of the environment (for example, heat from the earth) [24]. Organizations that have renewable energy contracts or technologies might be less willing to also adopt energy-saving technologies required by regulations and laws.

In the following sections, we discuss factors that influence the adoption of energysaving technologies.

\subsection{Economic Advantage and Perceived Relative Advantage}

Economic advantage relates to financial gains. Following from Article 2.15 of the Dutch environmental control law, the "payback" time of five years suggests that the energy reduction measures save a sufficient amount of money per year to earn a return of investment within five years. After these five years, the saved amount of money increases the financial performance. Hence, we expect that the measure's absolute economic advantage is one reason that organizations adopt energy-saving technologies. However, an economic advantage is not the only factor that may convince organizations to adopt a technology. Rogers [15] (p. 229) introduces the broader concept 'relative advantage', defining it as "the degree to which an innovation is perceived as better than the idea it supersedes". The degree of relative advantage may be measured in economic terms, but also in terms of social prestige, convenience, and satisfaction. This is included in our research. The most important aspect here is whether the decision-making unit perceives the innovation (in this case energy-saving technology) as beneficial. In addition, relative advantage is one of the best predictors in the rate of adoption; the greater the perceived relative advantage of an innovation, the more rapid its rate of adoption will be [15]. This conforms with the findings of Weng and Lin [25], who found that the perceived relative advantage has a positive impact on clean technology adoption in organizations.

\subsection{Institutional Pressures}

Organizations do not always behave according to their economic interests. Institutional pressures may also require organizations to adopt innovations, according to insights from institutional theory $[17,26-28]$. Institutional theory provides a rich and complex view of organizational behavior, e.g., [28]. From an institutional perspective, social influence toward conformity shapes an organization's actions [26]. Under certain conditions, several pressures may lead organizations to be "legitimated" in order to survive in the market [29]. Institutional theory recognizes three institutional pressures: coercive pressure, mimetic pressure, and normative pressure [17]. Mimetic pressures from peer organizations and normative pressures from professional and societal associations may also play a role. However, this research mainly focusses on coercive pressures from governmental bodies, in line with the Dutch context of the environmental control law. Scott [30] uses the more precise term of regulatory pressures instead of the broader term coercive pressures. Regulatory pressures are derived from rules, controls, rewards, and sanctions, typically exerted by governments that ultimately have the power to recognize or deny an organization's existence in their jurisdiction [26]. Therefore, in this research, the Dutch environmental control law is considered a regulatory pressure.

\subsection{Factors Related to Regulatory Pressure}

\subsubsection{Organizational Awareness and Strictness of Maintenance of the Environmental} Control Law

When an organization is not aware of the existence of a law or the rules it prescribes, the chance that it will adopt energy-saving technologies is smaller. Organizations will feel no regulatory pressure if they are ignorant of the laws that are obliging them to adopt certain energy-saving technologies. On the other hand, when organizations are aware of the laws, and the potential consequences of not complying, we expect that they will feel greater regulatory pressure and, therefore, will earlier adopt energy-saving technologies. 
This feeling of greater regulatory pressure can be realized through stricter maintenance. As environmental regulatory pressures increase, the adoption of environmental innovations increases, accordingly [26]. One explanation for this is that firms have greater incentives to comply when they face both higher probabilities of being detected (regarding illegal behavior due to higher monitoring) and/or they are subject to tougher sanctions [26]. Their propositions are reminiscent of the so-called Porter's hypothesis; stricter environmental regulations might lead to innovation and, thus, competitive advantages [31]. Thus, the question arises as to whether regulatory pressures influence organizations to adopt technology, as well as whether the way (e.g., strict or not) in which the government maintains its regulations makes a difference in the adoption behaviors of organizations that must comply. For example, the frequency of municipal inspections may influence an organization's adoption behaviors. When stricter regulations are launched, organizations are more likely to adopt more advanced technologies [32].

However, from the perspective of organizations that must comply with the law, the experiences that these organizations have (e.g., with the maintenance of authorities) need to be scrutinized. "Experienced" maintenance of the environmental control law is divided into two parts in this research: the experienced monitoring of the law (frequency of inspections) and the experienced pressures from possible sanctions. By doing this, we provide an evident view on how organizations experience pressure from regulations, in this case, the environmental control law.

\subsubsection{Willingness to Comply with the Law and Regulatory Conflict}

The existence of institutional voids might be another possible reason for (non-)adoption of the energy-saving technologies under the jurisdiction of the environmental control law. Institutional voids are commonly defined as "gaps between rules and their purpose and the effectiveness of their implementation" [33] (p. 5). An institutional void exists when there are no clear rules and norms according to which politics (from different institutions) are to be conducted and measures are to be agreed upon [34]. In addition, these rules, regulations, or measures from different institutions may even conflict with each other because of different goals, which is called regulatory conflict [35]. This suggests that some organizations are actually willing to comply with the law, but due to regulatory conflicts, they eventually choose not to adopt energy-saving technologies.

\subsubsection{Other Factors}

First, strictness (regarding municipal maintenance) may create awareness of the law. It is likely that organizations will not follow (or will be less aware) of the law, its prescriptions, and consequences, if municipalities hardly monitor whether these organizations obey the law. In addition, this will influence the organization's willingness to comply with the law, since being aware of the law and the consequences of not complying, will likely lead to more of a willingness to avoid these consequences. The relative advantages of technology are also expected to affect an organization's willingness to comply with the law, as the higher the relative advantages for organizations, the more likely organizations will adopt energy-saving technologies.

Furthermore, if there is regulatory conflicts, for example surrounding the environmental control law, relative advantages of technologies might play less important roles in whether a technologies are adopted or not, because the conflict will lead to stagnation of the adoption process. On the other hand, if an organization is aware of the consequences of ignoring the law, the perceived relative advantage will be a starting point in considering the energy-saving measures to adopt.

\section{Research Methods}

This research is exploratory, because theories explaining (non-)adoption behaviors of organizations and specifying the conceptual (inter)relationships and their underlying mechanisms are hardly available in the context of law regulations, such as the environ- 
mental control law. In such a research approach, a case study method aimed at obtaining an in-depth understanding of a phenomenon in a real-life setting is the best alternative compared to a survey or experiment [36]. We conducted a 'multiple mini-case' study with six cases, for two reasons: first, it retains the holistic and meaningful characteristics of contemporary real-life events with broad insights, allowing for theoretical and literal replication [36]. Second, the firms involved under the scope of the environmental control law are rather small, which limited our access to multiple relevant informants.

In addition, these six cases were deliberately selected using the following criteria. First, the firms were part of the sectors in which the environmental control law applied. As it happens, the knowledge center InfoMil [37] published the measures list "acknowledged measures for energy-saving": a tool for municipalities and organizations concerning all energy measures prescribed by the environmental control law. The list of "acknowledged measures for energy-saving" presents the mandatory energy-saving measures for twelve sectors [37]. Organizations are able to use this list to ascertain whether they follow the required measures, and municipal- and environmental services can use this list of measures when checking firms [21]. Second, we chose the two industrial sectors-metalworking and electrical engineering, and synthetic material and rubber - on the list. These are the heavy energy users with the largest estimated energy-saving potential [21]. Third, within these two industrial sectors, three organizations per sector were approached. For the law to apply to the organizations, the organization has to use a minimum of $50,000 \mathrm{~kW} / \mathrm{h}$ electricity or $25,000 \mathrm{~m}^{3}$ of natural gas equivalents per year [37]. The six case firms meet this criterion.

We used a mixed-method approach of interviews and a questionnaire for triangulation reasons [38,39]. Interviews were held with informants in firms and governmental environmental services. For each firm, an interview took place with a decision-maker or a person who actively influenced the decision-making process concerning the adoption of energy-saving technologies in the organization. Table 1 shows information about the informants of the firms(names are fictitious for confidentiality reasons). Prior to these interviews, an interview was held with the advisor of the Maintenance of the Environment, working in environmental service in Nijmegen, The Netherlands. This advisor provided relevant information about the actual maintenance of the environmental control law in environmental services in Nijmegen.

Table 1. Information about cases.

\begin{tabular}{|c|c|c|c|c|c|c|}
\hline Name & $\begin{array}{l}\text { 1. Johnson } \\
\text { Metalworking }\end{array}$ & $\begin{array}{l}\text { 2. Metal } \\
\text { Solutions }\end{array}$ & $\begin{array}{l}\text { 3. Williams } \\
\text { Group } \\
\text { Engineering }\end{array}$ & $\begin{array}{c}4 . \\
\text { Poly-Solutions }\end{array}$ & $\begin{array}{l}\text { 5. Synthetic } \\
\text { Change Inc. }\end{array}$ & 6. Pipes \& Co \\
\hline Sector & $\begin{array}{c}\text { Metalworking } \\
\text { and electrical } \\
\text { engineering }\end{array}$ & $\begin{array}{l}\text { Metalworking } \\
\text { and electrical } \\
\text { engineering }\end{array}$ & $\begin{array}{l}\text { Metalworking } \\
\text { and electrical } \\
\text { engineering }\end{array}$ & $\begin{array}{c}\text { Synthetic } \\
\text { material and } \\
\text { rubber }\end{array}$ & $\begin{array}{l}\text { Synthetic } \\
\text { material and } \\
\text { rubber }\end{array}$ & $\begin{array}{c}\text { Synthetic } \\
\text { material and } \\
\text { rubber (also } \\
\text { metalworking) }\end{array}$ \\
\hline $\begin{array}{l}\text { Number of } \\
\text { employees }\end{array}$ & 9 & 20 & $30-40$ & 50 & 45 & 20 \\
\hline $\begin{array}{c}\text { Age of } \\
\text { informant } \\
\text { (years) }\end{array}$ & 47 & Unknown & 39 & 54 & 49 & 37 \\
\hline $\begin{array}{l}\text { Position of } \\
\text { informants }\end{array}$ & Owner & $\begin{array}{l}\text { Owner- } \\
\text { managing } \\
\text { director }\end{array}$ & Manager & Manager & Plant-manager & $\begin{array}{l}\text { Process- } \\
\text { manager }\end{array}$ \\
\hline
\end{tabular}

Based on Hertel and Menrad [10], willingness to comply with the environmental control law was measured by asking questions about a firm's current intentions to adopt energy-saving technologies, the continuous overall intentions to adopt energy-saving technologies, and specific intentions to comply with the environmental control law. By doing 
this, the willingness to adopt energy-saving technologies in general, and the willingness to comply with the law, were measured separately, for discriminant validity reasons.

Prior to the interview, each interviewee was requested to fill in a questionnaire. This questionnaire consisted of the energy-saving technologies that were required for firms in both sectors, based on the measures list from InfoMil [37]. The purpose of this questionnaire was to confirm whether the informants understood what was meant by the concept 'energysaving technologies' and to verify which technologies were already adopted.

The interviews were fully transcribed and coded manually. Insights into the underlying patterns of the situations were gained by comparing fragments within the same dimensions, following Miles and Huberman [40]. The explanation building technique was the specific data analysis technique used [36]. This is a special type of pattern matching that is used to analyze case data by building explanations for the behavior observed. Finally, the different dimensions were gathered to build conceptualization processes across cases.

\section{Results}

All six firms adopted several energy-saving technologies. However, the number of adopted technologies varied among the firms, as shown in Table 2. The questionnaire included 16 technologies in total. The metalworking and electrical engineering sector are abbreviated as M.E. and the synthetic material and rubber sector are abbreviated as S.R.

Table 2. Amount of (non-)adopted energy-saving technologies.

\begin{tabular}{|c|c|c|c|c|c|c|}
\hline & $\begin{array}{l}\text { 1. Johnson } \\
\text { Metalworking }\end{array}$ & $\begin{array}{l}\text { 2. Metal } \\
\text { Solutions }\end{array}$ & $\begin{array}{l}\text { 3. Williams } \\
\text { Group } \\
\text { Engineering }\end{array}$ & $\begin{array}{c}4 . \\
\text { Poly-Solutions }\end{array}$ & $\begin{array}{l}\text { 5. Synthetic } \\
\text { Change Inc. }\end{array}$ & 6. Pipes \& Co \\
\hline $\begin{array}{l}\text { Number of } \\
\text { technologies } \\
\text { adopted }\end{array}$ & 10 & 3 & 11 & 9 & $\begin{array}{c}13 \text { (among } \\
\text { which } 3 \text { partly } \\
\text { adopted) }\end{array}$ & 6 \\
\hline $\begin{array}{l}\text { Number of } \\
\text { technologies } \\
\text { not adopted }\end{array}$ & 3 & 6 & 3 & 4 & 2 & 4 \\
\hline $\begin{array}{c}\text { Number of } \\
\text { technologies } \\
\text { not applicable }\end{array}$ & 3 & $7^{a}$ & 2 & 3 & 1 & 4 \\
\hline $\begin{array}{l}\text { Number of } \\
\text { technologies } \\
\text { unknown by } \\
\text { respondent }\end{array}$ & 0 & 0 & 0 & 0 & 0 & 2 \\
\hline & sa & $\begin{array}{l}\text { informant } \\
\text { ous amoun } \\
\text { or not adol }\end{array}$ & $\begin{array}{l}\text { hat seven tech } \\
\text { y. It is doubtf }\end{array}$ & $\begin{array}{l}\text { ies were not appl } \\
\text { lether these answ }\end{array}$ & $\begin{array}{l}\text { le because, in his } \\
\text { belong to the nur }\end{array}$ & $\begin{array}{l}\text { ion, they would n } \\
\text { of technologies n }\end{array}$ \\
\hline
\end{tabular}

The results of Table 2 show that no firm adopted every energy-saving measure that the environmental control law prescribes. However, all six firms used substantially more energy than the minimum amount $\left(50,000 \mathrm{kWh}\right.$ or $25,000 \mathrm{~m}^{3}$ of natural gas equivalents per year). Therefore, they did not comply with this part of the environmental control law, despite the obligation to do so. During the interviews, we did not receive an indication that firms obviated from the environmental control law by adopting renewable-energy technologies, making the adoption of energy-saving technologies unnecessary. One firm used solar panels, while the others were considering it, but this was seen as additional and not as a substitute for the energy-saving technologies.

\subsection{Awareness of the Environmental Control Law}

All informants had heard about the environmental control law. However, no informant could precisely elaborate on what the law specifically entailed. Most informants attempted 
to give explanations, which overall covered parts of the content of the law. As the owner of Johnson Metalworking stated: "I believe you need a plan with which you can show what kind of measures you took to save energy". However, he did not make such a plan at that time; it was just a general idea he had. The answer from informant 6 came closest to the actual content of the environmental control law: "To a lesser extent, I know what it entails. I guess that we as a firm must comply with certain guidelines. You have to invest in certain environmental measures, provided that it has a certain payback period" (process-manager at Pipes\&Co). Notwithstanding this, he was unaware of the different measures that existed; this was a task to complete in the future. However, he expected that his superior knew more about the Law, "because he has a lot more experience". Only informants 4 and 5, both working in synthetic material firms, were supported by others inside and outside the firm, to keep updated about the environmental control law requirements. Thus, the informants seemed aware of the existence of the environmental control law; however, most of them did not know the content. Remarkably, a lack of awareness of the law does not seem to fully explain non-adoption when looking at the energy-saving technologies adopted by the firms, e.g., the process manager of Pipes\&Co was aware that it is mandatory to adopt certain measures and his superior was thought to be familiar with the law as well, while informant 3 (manager at Williams Group Engineering) and his colleagues were fully unaware about the content of the law. Nevertheless, Williams Group Engineering adopted considerably more energy-saving technologies than informant 6 's firm, Pipes\&Co (respectively, 11 and 6 out of the necessary 16). This is closely related to the informants "experienced maintenances of the municipalities". This will be further explained in the next section.

Therefore, we propose:

Proposition 1. An organization's lack of awareness of the environmental control law does not entirely block the adoption of all energy-saving technologies, as a firm adopts certain energy-saving technologies in spite of its ignorance of the obligations.

\subsection{Experienced Monitoring Regulatory Compliance}

All informants, except for the owner of Metal Solutions, had experience with inspections from the municipality and/or Environmental Services concerning energy-saving. However, it became clear that these inspections focused on other requirements, such as pollution, emissions, transport, and water outlets. Generally, the informants' perceptions of the environmental control law was based on these topics, as the only topics inspected. In addition, during the interview, the informants were told that the technologies listed in our questionnaire were based on the environmental control law, and were therefore compulsory. None of the informants had knowledge about this, not even informant 6, who was aware of the existence of mandatory measures. The plant manager of Synthetic Change, Inc. even seemed astonished: "But well, the environmental control law does not prescribe that, for example, I need to use energy-efficient lighting. [ . .. I Is that the new environmental control law?". The manager of Pipes\&Co admitted that, during the most recent inspection, the inspectors commented that "the energy-saving part" should be focused on more in his firm. Despite this comment, his firm was not reinspected, subsequent to that last inspection: "No, it is not checked. We haven't even, uhh, looked at what energy-saving measures we could adopt here" (Process-manager, S.R.). Therefore, it is possible to conclude that, concerning the monitoring of the obliged measures included in the environmental control law, no firm has ever been enforced to adopt the mandatory measures by the inspector.

Therefore, all of the informants were unaware of the possible sanctions that came with disobeying the environmental control law. Although they generally felt that sanctions could serve as a threat, they never experienced these specific sanctions or the threat thereof, related to the required measures. Therefore, it had no impact on their decision-making concerning new energy-saving technologies. "When nobody checks on you, you won't feel any pressure" (Owner of Metal Solutions). Informants 1 and 3 also noted that they felt they were 
already doing well, so this also contributed to the lack of feeling any pressure from possible sanctions. "We have nothing to do with sanctions, so therefore I don't feel any pressure from it" (manager at Williams Group Engineering).

The additional interview with the advisor of the Maintenance of the Environment explained these results. He declared that the article concerning the measures of the environmental control law was founded in 1994. It was only since 2006 that the municipality of Nijmegen increased its monitoring in regard to organizations adopting energy-saving measures. In 2013, these activities were taken over by the Environmental Services, a service commissioned by the municipality of Nijmegen to conduct inspections. Nevertheless, up until recently, no explicit measures lists had existed, since there was only a general rule that applied to all organizations, stating: "Organizations must take all measures with a payback time of five years or less". This was "insufficiently clear to people who had to inspect organizations as well as to the organizations themselves", so this part of the environmental control law was largely neglected. In 2016, specific measures lists were formulated for twelve sectors, with measures that proved to have a payback time of five years or less. These lists appeared to be more credible and understandable, in such a manner that Environmental Services finally had an instrument to actively start enforcing organizations to adopt. Nonetheless, Environmental Services lacked the personnel and time to monitor and enforce all organizations in the twelve sectors to adopt the obligatory energy-saving measures on short notice. They made a plan, aiming to visit each sector successively. "We will start with the swimming pools, considering their high use of energy. Then we are going to approach the big offices, and then we get to the secondary-and primary schools". When asking about the metalworking/electrical engineering sector and the synthetic material/rubber sector, they confirmed that these sectors had not been inspected. Additionally, the Environmental Service is not planning to inspect these sectors on the energy-saving measure uses in the near future. These explanations elucidated the informants' lack of awareness concerning this part of the environmental control law and its accompanying consequences when not complying.

\subsection{Willingness to Comply with the Environmental Control Law}

4.3.1. Willingness to Comply with Regulations

Concerning the straightforward question: "Do you have the intention to comply with the environmental control law?", it is not very surprising that all of the informants answered they had this intention. However, the owner of Metal Solutions answered "yes", but in the meantime he shook his head 'no', showing his answer was socially desirable; it is doubtful whether he really has this intention. He explained: "I know too little about it now, it is difficult to say what I am going to do.". Informant 3 (manager at Williams Engineering) also stated: "The intention is always there. But it depends on the rules, and I don't know what they entail right now. I assumed they are already check on those things and that we are doing fine". This confirms that it is hard to say that firms are willing to comply with a part of the law with which they are not familiar with. However, in general, firms acknowledged being willing to comply with any law because it was mandatory. The process manager at Pipes\&Co added: "I assume we do, yes. But I think it is not the law per se, it also comes from an inherent willingness to be environmentally conscious". Therefore, the previously mentioned results concerning awareness, experienced law maintenance, and willingness to comply with regulations show that, without the actual enforcement of a law, organizations will not adopt all of the energy-saving technologies. However, the results from the questionnaire show that the firms adopted at least three technologies, so there must be other incentives or drives to adopt these technologies.

\subsection{2. (Un)Willingness to Adopt Energy-Saving Technologies}

A firm's overall intention to adopt energy-saving technologies, involves the current intentions to adopt energy-saving technologies on the list from the environmental control law. Results show that, once the informants get the opportunity to equip their firms with state-of-the-art technology, to save energy, none of them claimed that they did not want 
to do that. However, informants mentioned some prerequisites. Informants 1 and 2, both owners of metalworking firms, required proof that the technology actually worked. "I really have to be confident about it, I want to know whether in practice it does what it is expected to do" (informant 1). Informant 3, manager at Williams Group Engineering, stated that his firm just wanted to keep up-to-date; it had no desire to play a pioneering role. Two managers in S.R. explicated that the payback time of the technology has to be sufficiently short. The manager at Poly Solutions added: "I am not going to say that I will immediately invest in these technologies for the reason that I have the possibility to do this, because the firm also has to stay viable".

The informants were also asked about their continuous overall intentions. When asked whether they constantly monitored different options for using energy-saving technologies in their firm, some informants (1 and 5) acknowledged this. "I keep myself updated, yes. We often visit fairs or the energy platform, which regularly gives lectures or workshops" (informant 5 , plant-manager at Synthetic Change, Inc.). Two others (3 and 4, managers in, respectively, M.E. and S.R.) answered that they also kept up with new developments, but to a lesser extent. They occasionally read e-mails about new technologies, but not much more than that. The process manager of Pipes\&Co stated that he had never checked for options to use energy-saving technologies at his firm, because his firm was just about to consider energy-efficiency. The Metal Solutions owner explained: "As long as you don't have the money to invest in something new, it makes no sense to keep checking on it. I start to check on it when I am really planning to buy it". Noteworthy, the informants with low continuous intentions to adopt energy-saving measures (cases 2 and 6) in practice also adopted considerably less technologies than the ones with high continuous intentions (cases 1, 3, and 5). Therefore, it is assumed that the lack of intention continuity affects the adoption of these technologies. Thus, firms seem to have a general willingness to comply with the law, but because they are not familiar with this part of the environmental control law, it is hard to say if they are also willing to comply with the energy-saving part. This suggests that the awareness and experienced law maintenance of this part of the environmental control law influence a firm's willingness to comply with this part of the law.

Proposition 2. An organization's lack of awareness of the environmental control law influences its willingness to comply with the environmental control law, because organizations are less intended to comply if they do not even know with what law they have to comply with.

Proposition 3. Experienced law maintenance by municipalities influences an organization's willingness to comply with the environmental control law, because inspections and sanctions serve as a threat.

Proposition 4. An organization's willingness to comply with the environmental control law positively influences its adoption of energy-saving technologies, because having the intention to comply with a law, and to adopt an energy-saving technology, increases the chances of an organization adopting the energy-saving technology.

\subsection{Regulatory Conflict}

Interviews showed that the informants did not experience any regulatory conflicts. They could not mention regulations that contradicted the environmental control law. Furthermore, no other institutions, such as governments and NGOs, had contact with informants about energy-saving technologies. Therefore, in these cases, there was no evidence that regulatory conflicts played a role, let alone had a negative influence on an organization's willingness to comply with the environmental control law. However, informant 2, the Metal Solutions owner, believed that the Dutch government would never want organizations to save energy: "No, they are getting the VAT because of this [energy use]! The moment we all become energy-neutral, the government has a problem, so that's very contradictory". Therefore, some organizations might have the notion that although this law exists, the government 
does not want to enforce it, because it will become a victim of regulation. Although this cannot be designated as a regulatory conflict, it shows that organizations might experience different signals from authorities that might contradict each other. Consequently, a firm's owner prioritizes signals from the government above the actual existence of the law and, therefore, is less willing to adopt the mandatory energy-saving measures. This leads us to propose:

Proposition 5. Contradictory signals from authorities can hinder an organization's willingness to comply with the environmental control law, because it attenuates the pressure to comply.

\subsection{Economic and Relative Advantages}

\subsubsection{Economic Advantage}

Concerning which factors influenced the decision to adopt an energy-saving technology, in all cases, economic advantage was mentioned was the most important one. "Well, the biggest factor for energy-saving technologies is just to reduce costs, that it brings in money" (manager at Williams Engineering). "In the first place, money is the most important factor, that it saves money. [ . . . I It has to be commercially achievable to adopt" (owner of Johnson Metalworking). This demonstrates that the absolute economic advantage of the energy-saving technology for an organization has a positive influence on the adoption intention of the energy-saving technology. Every informant also realized that the technologies prescribed by the environmental control law had economic advantages. However, the interviews also showed that the payback time of the energy-saving technology was an additional important point of discussion related to the economic advantages. Opinions about this payback time of five years or less differed among cases. Firstly, informant 4 , the manager at Poly Solutions, mentioned that his organization used a shorter payback time, namely two years: "We want any investment to be paid back within two years. If that's the case, it's almost $a$ "no-brainer", then we are investing most of the times". The process manager of Pipes\&Co explained that his firm was going to relocate to another building within two years and, therefore, postponed all investments that had a payback time longer than two years. On the other hand, the manager at Williams Engineering mentioned that the payback time of five years did not play any role when an investment decision had to be made, because his firm had the financial resources for longer investment times. Lastly, the two owners of a metalworking firm appeared to be skeptical towards the payback time of five years, because in their organization, the energy use of a technology was not always as high as the calculated energy use. For example, the manager of Metal Solutions stated that he did not use a high-efficiency boiler instead of a conventional boiler because he rarely used this boiler, so this would not be paid back within five years. Therefore, the absolute economic advantage of an energy-saving technology appeared to only have a positive influence on adopting this energy-saving technology if the organization perceived its payback time as sufficient.

\subsubsection{Relative Advantage}

In most cases, energy-saving measures do not provide important benefits, other than economic benefits, including the convenience, productivity, and/or quality of their organization. Only one informant, the plant-manager of Synthetic Change, Inc., could think of some influence, stating that: "It can improve the quality of the product, but also the quality of working conditions or the well-being within the firm. Because if you isolate, such a pipe releases less heat, and then it is more comfortable to work in such a hall". Thus, he believed that some energy-saving technologies could improve working conditions in comparison with traditional techniques.

All informants, except informant 2, believed that when organizations actively communicate with the outside world that they save energy it has a positive influence on the organization's reputation. Informants $(3,4,5)$ even argued that firms can obtain and attract customers. "A few years ago, our firm invested in new energy-saving equipment. [ . . . I It's 
also a way of marketing yourself. When you are walking through the workshop with customers, they will also see that the machine park looks very neat" (manager at Williams Engineering). However, informant 4 added that it is not always noteworthy to inform customers that a firm has adopted specific, smaller measures, such as using LED lighting. Nevertheless, it does have an influence on the employees in the organization. Therefore, the energysaving measures can positively influence the image of the organization in the eyes of customers and employees and could improve working conditions, in comparison with traditional techniques. Informants also liked the idea that it saved energy and therefore is better for the environment; this was also seen as an important advantage in comparison to traditional techniques.

To summarize, we expect that the higher the perceived relative advantages of energysaving technologies for organizations, the higher the probability of these organizations adopting energy-saving technologies (and the other way around). Besides economic advantages, other important advantages include improvement of the organization's reputation and working conditions, and the general idea that the firm is environmental-friendly. These advantages may compensate for the costs of adoption time and effort, as the owner of Johnson Metalworking argued.

One barrier preventing firms from adopting energy-saving technologies is giving priority to other important investments over energy-saving technologies. However, this is not included in the perceived relative advantages of a technology, because it concerns investments with different goals. The manager of a larger synthetic material firm, for example, stated that the definite budget constrains the amount of money he could spend. Consequently, firms have to choose between various investments according to their usefulness. For example, the plant-manager of Synthetic Change, Inc. believed that if he had to choose between a new machine or investing in solar energy, he would choose the new machine, because "our operations are more important than the environmental interests". Informant 2, the owner of the smaller firm, Metal Solutions, also believed "financial dilemmas can be a big obstacle. Firms invest more easily in the things that directly and visibly bring in money. And those are not the energy-saving measures. [ ... I If at any given time I had to choose between a new truck, or solar panels... Yes, it is going to be the truck. Within three months this one becomes defective, so that must come first". Therefore, other investment decisions appeared to negatively influence the adoption of energy-saving technologies. Therefore, we propose:

Proposition 6. The absolute economic advantage of an energy-saving technology has a positive influence on the adoption of this energy-saving technology if the organization perceives its payback time as sufficient.

Proposition 7. The absolute economic advantage of an energy-saving technology has a positive influence on the perceived relative advantage.

Proposition 8. Perceived relative advantage has a positive influence on the adoption of energysaving technologies.

Proposition 9. Other investment decisions may lead to non-adoption of energy-saving technologies when these investments are perceived as more important and are therefore prioritized.

\subsection{Additional Relationships}

Experienced municipal maintenance determines the awareness of the law. Because municipalities hardly monitor organizations that comply with the law, organizations are less aware of the law, its prescriptions, and consequences. In addition, this may influence a firm's willingness to comply with the law, since being aware of the law and the consequences of not complying are expected to lead to more willingness to avoid these consequences. On the one hand, this can be confirmed, as informants indicated that sanctions could serve as a threat. One the other hand, because informants were not fully aware of this part of the environmental control law, it is not feasible to say that their willing- 
ness to comply with the law was influenced. Additionally, informants stated that, at that moment, they did not feel any pressure from consequences of not complying, since they already adopted energy-saving technologies themselves. Therefore, it also involves an organization's inherent willingness to save energy, not solely its willingness to comply with a law. Moreover, relative advantage was expected to have a positive influence on the willingness to comply with the environmental control law. Instead of influencing a firm's inherent willingness to comply with regulations, the interviews show that relative advantage influences the willingness to adopt energy-saving technologies, prescribed by regulations, because the intention to adopt logically depends on the (dis)advantages of the certain technology of the firm.

Furthermore, the relationship between perceived relative advantage and the adoption of energy-saving technologies was expected to be positively moderated by awareness of the environmental control law. This is hard to confirm, because informants were not fully aware of the investigated part of the environmental control law. Nevertheless, this lack of awareness did not negatively influence the relations between the perceived relative advantage on adopting certain energy-saving technologies, because all of the informants' firms adopted energy-saving technologies without being aware that they were legally required to do so. Lastly, the relationship between perceived relative advantage and adopting energy-saving technologies was expected to be negatively moderated by regulatory conflicts. However, there was no actual regulatory conflict suggested during the interviews, only contradictory signals from authorities.

Proposition 10. An organization's lack of awareness of the environmental control law was not the only factor influencing the effect of the perceived relative advantage on the adoption of certain energy-saving technologies.

Proposition 11. The perceived relative advantage of an energy-saving technology is expected to have a positive influence on a firm's willingness to comply with the environmental control law.

Proposition 12. A lack of experienced municipal maintenance negatively influences an organization's awareness of the environmental control law because inspections from municipalities are seen as the main sources of information concerning the environmental control law.

\subsection{Conceptual Model}

To visualize the results of this analysis, a conceptual model was made and presented; Figure 1. In addition, propositions are presented to describe the relations between concepts.

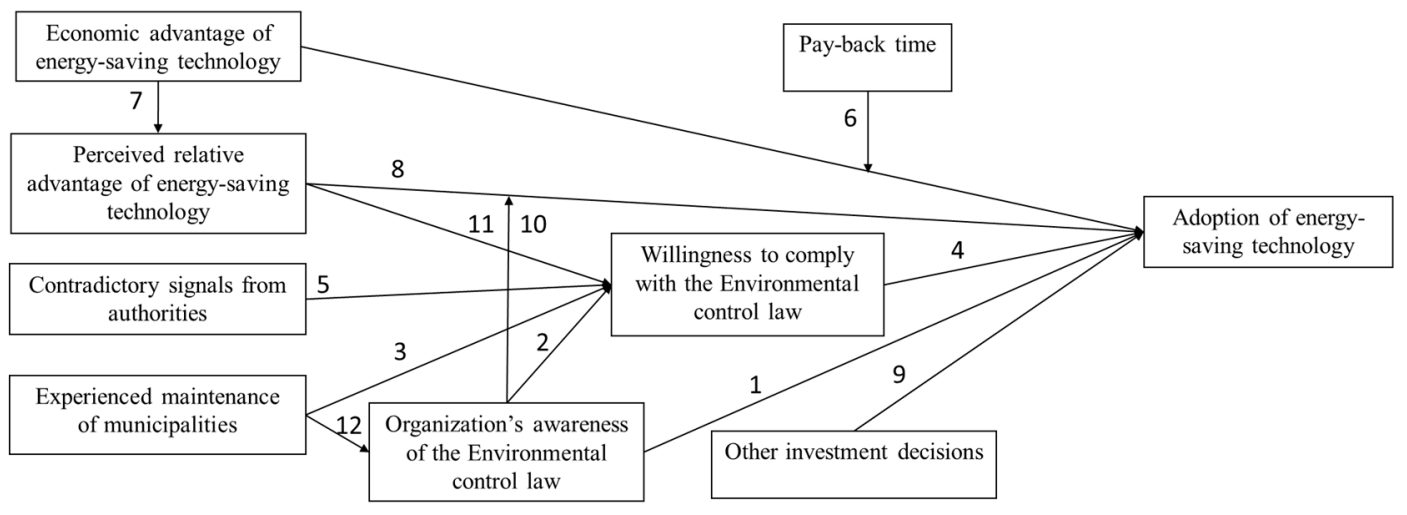

Figure 1. Conceptual model.

\section{Conclusions and Discussion}

This research aimed to increase our understanding on the factors that facilitate, hinder, or block the adoption of energy-saving technologies. The main reason some firms adopt energy-saving technologies and other firms do not, although they are all legally required to 
do so, is not the regulatory pressure from the environmental control law. No firm in our research was aware of the legal obligations to adopt these technologies. However, in order to adopt the technologies, decision-makers must be convinced that adopting energy-saving technologies benefit the organizations, and that the payback time is sufficient. However, some firms are struggling with financial dilemmas, which force them to choose between investing in energy-saving technologies or in other areas. Very often, other investments in, for example, machinery or new vehicles, are preferred. Another factor is the awareness of energy-saving technologies. Firms that regularly visit lectures and workshops, and that read e-mails in which new technologies are presented, tend to adopt these technologies earlier. Firms that do not have these continuous intentions to adopt energy-saving technologies appeared to, eventually, adopt significantly less technologies.

In particular, in line with the adoption theory [15], economic advantages, in addition to other relative advantages, are proposed to have positive influences on the adoption of energy-saving technologies. Economic advantage was the most important factor influencing a firm's decision to adopt. Moreover, other advantages, such as improvement of working conditions and a firm's reputation in the minds of customers and employees, played important roles. However, the payback time of five years, used to determine the technologies required by the environmental control law, appeared to be an important barrier. Some firms only invested in technologies with shorter payback times, or the energy use of certain technologies was not always as high as the calculated energy use. Thus, in practice some technologies were not expected to be paid back within five years. Therefore, the absolute economic advantage of an energy-saving technology appeared to have a positive influence on a firm adopting this energy-saving technology only if the firm perceived its payback time as sufficient.

None of the informants was aware of all mandatory measures (included in our questionnaire) from the environmental control law. However, an organization's lack of awareness on the environmental control law was not the main factor hindering the adoption of certain energy-saving technologies nor the relationship between the perceived relative advantages and the adoption of certain energy-saving technologies, as firms adopted certain energy-saving technologies in spite of their ignorance. Informants did seem to be willing to comply with the law, based on the general willingness to obey the regulations and due to their intentions to adopt energy-saving technologies. In particular, firms' continuous intentions to adopt energy-saving technologies appeared to be positively related to the number of adopted technologies. The interviews also showed that informants had never been inspected in regard to adopting the compulsory energy-saving technologies, because the inspections from the Environmental Services (or the municipality) only focused on other environmental-related requirements that were also included in the environmental control law. This lack of experienced maintenance negatively influenced organizational awareness of the environmental control law, since the idea of this law is based on the topics in which they (organizations) are inspected. Therefore, evidence suggests that without the actual enforcement of the law, firms will not adopt all of the measures that are required.

Regulatory conflict was only found in a firm that experienced contradictory signals from authorities, which attenuated the pressure to comply with the environmental control law.

\subsection{Theoretical Implications}

This research included reasons for non-adoption, overlooked in previous research, as also indicated by Frambach and Schillewaert [14]. Although Gatignon and Robertson [16] argued that we must not automatically believe that non-adoption is the mirror image of the adoption decision, this research did not reveal reasons not to adopt a technology, which could not be seen as the opposite of a reason to adopt, when using organizational adoption theory as a starting point. However, some factors, including the lack of awareness of the regulation and unwillingness to comply with the regulation, explain the non-adoption of all mandatory technologies, though there are differences from one firm compared to another, and these factors are influenced by others. Nevertheless, these factors represent 
institutional pressures that have not been described as external pressures in previous studies that take an organizational adoption perspective following [14].

Moreover, our findings are in line with previous investigations showing that economic and relative advantages are the most important factors influencing the decisions to adopt energy-saving technologies. This research also replenishes previous studies about organizational adoption of technologies, e.g., $[17,20,26]$, and about adopting energy-saving technologies [2,5-7], by showing the influence of legal obligations on adopting energysaving technology behavior. Previous studies find regulatory and normative pressures as conditions under which firms pursue environmental innovations, see, e.g., [20,26], the means to stimulate awareness to preserve energy, and incentives to reduce implementational costs of energy-saving technologies [5], subsidies that stimulate investments in energy efficiency [2], a mix of subsidies, taxes, and standards that are perceived to influence energy-saving investment decisions [6], and taxes/quotas in relation to early adoption of energy-saving technologies [7]. Our study explains an intricate set of conditions as to why firms do not adopt all mandatory energy-saving process technologies when firms face regulatory pressure in the form of a legal obligation: a law that demands investment behavior, including economic motive conditions.

Although researchers, such as Rogers [15], considered the adoption process as voluntary, this research demonstrated that that is not always the case. In addition, this research showed that although a legal obligation exists, firms are not automatically interpreting the adoption as involuntary. This, of course, relates to the finding that without actual enforcement of the legal obligation, firms do not feel any pressure from this obligation. Therefore, it also contributes to the institutional theory by showing that the regulation goals are only achieved when they are implemented right. The combined theory of Rogers adoption theory and the institutional theory will make researchers in the future more able to research an organizational adoption process in which regulations are involved.

\subsection{Limitations and Recommendations}

Despite the fact that a multiple mini-case study is more reliable than a one case study, results could have been more generalizable when more cases were conducted and more interviews were conducted in one organization [36]. Therefore, further research should include more cases to guarantee that the outcomes of the research entirely represent the larger population from which the sample is selected. It would be relevant as well to involve the other ten branches for which a measures list is published on InfoMil [37]. In addition, doing interviews with other female decision-makers is recommended, because this might provide new insights. Lastly, in this research, the mimetic and normative pressures, as part of the institutional theory, were not actively included because of the focus on the legal obligations. However, further research that includes these other pressures is recommended, to gain a better overall understanding of the situation. Institutional voids are signaled in one of our cases; other studies in different sectors may want to include that in order to address this topic in more detail.

\subsection{Practical Implications}

The results imply that managers of energy-intensive firms, even if their firm implements a sustainability policy that embraces energy-savings, may do more to become aware/familiar with governmental environmental laws tailored toward energy-saving issues. Even if these laws are not maintained as they should, and the economic and relative advantages, in addition to alternative investment options, may give reasons for a firm to not adopt energy-saving technologies, these laws may provide firms with longer lists of technological options available to adopt and save energy in the short run, which may help them to comply with the law and prevent sanctions and fines if law maintenance becomes stricter in the long run. For policy makers, these results imply that governmental commands and control interventions could be more effective if they are not creating voids and if firms are made aware of the long list of energy-saving technologies that are mandatory 
(following the law), and that monitoring and maintaining the law could play a role in creating awareness, following the law, even if maintenance is not optimally employed.

Author Contributions: Conceptualizations, C.G.C.v.H. and R.A.W.K.; methodology, C.G.C.v.H. and R.A.W.K.; formal analysis, C.G.C.v.H. and R.A.W.K.; writing-original draft preparation, C.G.C.v.H.; writing-review and editing, R.A.W.K. All authors have read and agreed to the published version of the manuscript.

Funding: This research received no external funding.

Institutional Review Board Statement: Not applicable.

Informed Consent Statement: Informed consent was obtained from all subjects involved in the study.

Data Availability Statement: Not applicable.

Conflicts of Interest: The authors declare no conflict of interest.

\section{References}

1. Borghesi, S.; Crespi, F.; D’Amato, A.; Mazzanti, M.; Silvestri, F. Carbon Abatement, Sector Heterogeneity and Policy Responses: Evidence on Induced Eco Innovations in the EU. Environ. Sci. Policy 2015, 54, 377-388. [CrossRef]

2. Garcia-Quevedo, J.; Jove-Llopis, E. Environmental Policies and Energy Efficiency Investments. An Industry-Level Analysis. Energy Policy 2021, 156, 112461. [CrossRef]

3. Pons, M.; Bikfalvi, A.; Llach, J.; Palcic, I. Exploring the Impact of Energy Efficiency Technologies on Manufacturing Performance. J. Clean. Prod. 2013, 52, 134-144. [CrossRef]

4. Palcic, I.; Pons, M.; Bikfalvi, A.; llach, J.; Buchmeister, B. Analysing Energy and Material Saving Technologies' Adoption and Adopters. J. Mech. Eng. 2013, 59, 409-417. [CrossRef]

5. Cunha, J.; Nunes, M.L.; Lima, F. Discerning the Factors Explaining the Change in Energy Efficiency. Environ. Dev. Sustain. 2018, 20, 163-179. [CrossRef]

6. Peneder, M.; Arvanitis, S.; Rammer, C.; Policy, T. Instruments and Self-Reported Impacts of the Adoption of Energy Saving Technologies in the DACH Region. Empirica 2021, 36. Available online: https://link.springer.com/article/10.1007/s10663-021-0 9517-6 (accessed on 1 October 2021). [CrossRef]

7. Van Soest, D.P. The Impact of Environmental Policy Instruments on the Timing of Adoption of Energy-Saving Technologies. Resour. Energy Econ. 2005, 27, 235-247. [CrossRef]

8. Meath, C.; Linnenluecke, M.; Griffiths, A. Barriers and Motivators to the Adoption of Energy Savings Measures for Small-and Medium-Sized Enterprises (SMEs): The Case of the ClimateSmart Business Cluster Program. J. Clean. Prod. 2016, 112, 3597-3604. [CrossRef]

9. Hrovatin, N.; Cagno, E.; Dolsak, J.; Zoric, J. How Important Are Perceived Barriers and Drivers versus Other Contextual Factors for the Adoption of Energy Efficiency Measures: An Empirical Investigation in Manufacturing SMEs. J. Clean. Prod. 2021, 323, 129123. [CrossRef]

10. Hertel, M.; Menrad, K. Adoption of Energy-Efficient Technologies in German SMEs of the Horticultural Sector-the Moderating Role of Personal and Social Factors. Energy Effic. 2016, 9, 791-806. [CrossRef]

11. Arvanitis, S.; Ley, M. Factors Determining the Adoption of Energy-Saving Technologies in Swiss Firms: An Analysis Based on Micro Data. Environ. Resour. Econ. 2013, 54, 389-417. [CrossRef]

12. Du, P.; Zheng, L.Q.; Xie, B.C.; Mahalingam, A. Barriers to the Adoption of Energy-Saving Technologies in the Building Sector: A Survey Study of Jing-Jin-Tang, China. Energy Policy 2014, 75, 206-216. [CrossRef]

13. Fu, Y.; Kok, R.A.W.; Dankbaar, B.; Ligthart, P.E.M.; van Riel, A.C.R. Factors Affecting Sustainable Process Technology Adoption: A Systematic Literature Review. J. Clean. Prod. 2018, 205, 226-251. [CrossRef]

14. Frambach, R.T.; Schillewaert, N. Organizational Innovation Adoption: A Multi-Level Framework of Determinants and Opportunities for Future Research. J. Bus. Res. 2002, 55, 163-176. [CrossRef]

15. Rogers, E.M. Diffusion of Innovations; Free Press: New York, NY, USA, 2003.

16. Gatignon, H.; Robertson, T.S. Technology Diffusion: An Empirical Test of Competitive Effects. J. Mark. 1989, 53, 35-49. [CrossRef]

17. DiMaggio, P.; Powell, W.W. The Iron Cage Revisited: Collective Rationality and Institutional Isomorphism in Organizational Fields. Am. Sociol. Rev. 1983, 48, 147-160. [CrossRef]

18. Yang, D.F.; Wang, A.X.; Zhou, K.Z.; Jiang, W. Environmental Strategy, Institutional Force, and Innovation Capability: A Managerial Cognition Perspective. J. Bus. Ethics 2019, 159, 1147-1161. [CrossRef]

19. Kemp, R.; Volpi, M. The Diffusion of Clean Technologies: A Review with Suggestions for Future Diffusion Analysis. J. Clean. Prod. 2008, 16, S14-S21. [CrossRef]

20. Chappin, M.M.; Vermeulen, W.J.; Meeus, M.T.; Hekkert, M.P. Enhancing Our Understanding of the Role of Environmental Policy in Environmental Innovation: Adoption Explained by the Accumulation of Policy Instruments and Agent-Based Factors. Environ. Sci. Policy 2009, 12, 934-947. [CrossRef] 
21. Wielders, L.M.L.; De Buck, A.; Leguijt, C. Energiebesparing via de Wet Milieubeheer: Raming van Het Potentieel in de Dienstensector en de Industrie. 2013. Available online: http://www.ce.nl/publicatie/energiebesparing_via_de_wet_milieubeheer/1375 (accessed on 19 December 2016).

22. Damanpour, F. Organizational Innovation: A Meta-Analysis of Effects of Determinants and Moderators. Acad. Manag. J. 1991, 34, 555-590.

23. Oikonomou, V.; Becchis, F.; Steg, L.; Russolillo, D. Energy Saving and Energy Efficiency Concepts for Policy Making. Energy Policy 2009, 37, 4787-4796. [CrossRef]

24. Ellabban, O.; Abu-Rub, H.; Blaabjerg, F. Renewable Energy Resources: Current Status, Future Prospects and Their Enabling Technology. Renew. Sustain. Energy Rev. 2014, 39, 748-764. [CrossRef]

25. Weng, M.-H.; Lin, C.-Y. Determinants of Green Innovation Adoption for Small and Medium-Size Enterprises (SMES). Afr. J. Bus. Manag. 2011, 5, 9154.

26. Berrone, P.; Fosfuri, A.; Gelabert, L.; Gomez-Mejia, L.R. Necessity as the Mother of 'Green' Inventions: Institutional Pressures and Environmental Innovations. Strateg. Manag. J. 2013, 34, 891-909. [CrossRef]

27. Meyer, J.W.; Rowan, B. Institutionalized Organizations: Formal Structure as Myth and Ceremony. Am. J. Sociol. 1977, 83, 340-363. [CrossRef]

28. Zhang, C.; Dhaliwal, J. An Investigation of Resource-Based and Institutional Theoretic Factors in Technology Adoption for Operations and Supply Chain Management. Int. J. Prod. Econ. 2009, 120, 252-269. [CrossRef]

29. Zucker, L.G. Institutional Theories of Organization. Annu. Rev. Sociol. 1987, 13, 443-464. [CrossRef]

30. Scott, W.R. Institutions and Organizations. In Foundations for Organizational Science; A Sage Publication Series: London, UK, 1995.

31. Porter, M.E.; Van der Linde, C. Green and Competitive: Ending the Stalemate. Harv. Bus. Rev. 1995, 73, $120-134$.

32. Popp, D. Exploring Links between Innovation and Diffusion: Adoption of NOx Control Technologies at US Coal-Fired Power Plants. Environ. Resour. Econ. 2010, 45, 319-352. [CrossRef]

33. Rodrigues, S. Understanding the Environments of Emerging Markets: The Social Costs of Institutional Voids; Erasmus Research Institute of Management: Rotterdam, The Netherlands, 2013.

34. Hajer, M. Policy without Polity? Policy Analysis and the Institutional Void. Policy Sci. 2003, 36, 175-195. [CrossRef]

35. Spatt, C.S. Regulatory Conflict: Market Integrity vs. Financial Stability. Univ. Pittsbg. Law Rev. 2009, 71, 625. [CrossRef]

36. Yin, R.K. Case Study Research: Design and Methods, 4th ed.; Sage Publications: London, UK, 2009.

37. Infomil. Energiebesparing en Winst. 2017. Available online: http://www.infomil.nl/milieumaatregelen/onderwerpen/ energiebesparing/. (accessed on 9 February 2017).

38. Jick, T.D. Mixing Qualitative and Quantitative Methods: Triangulation in Action. Adm. Sci. Q. 1979, 24, 602-611. [CrossRef]

39. Scandura, T.A.; Williams, E.A. Research Methodology in Management: Current Practices, Trends, and Implications for Future Research. Acad. Manag. J. 2000, 43, 1248-1264.

40. Miles, M.B.; Huberman, A.M. Qualitative Data Analysis, 2nd ed.; Sage Publications: Thousand Oaks, CA, USA, 1994. 